\title{
The British House Magazine 1945 to 2015: The Creation of Family, Organisation and Markets
}

\section{Business History}

Michael Heller, Senior Lecturer in Marketing, Brunel Business School, Brunel University, London, United Kingdom

Michael Rowlinson, Professor of Management and Organisational History, Exeter Business School, Exeter University, United Kingdom

This article examines the history of British house magazines from 1945 to 2015. It discusses their content, audience and function within companies. From tools of internal public relations, house magazines switched to being used as mediums of industrial relations in the 1960s and 1970 s, and by the late 1980s were increasingly applied to the creation of corporate identity, organizational culture and internal marketing. They were also forced to accommodate the rise of internal communications and electronic media. The paper discusses the rise and relative decline of the British house magazine, and ends by asking whether it has a future.

Key Words: House Magazines, Company Magazines, Internal Communication, Corporate Culture, Corporate Communications

House magazines appeared in Britain at the end of the nineteenth century. ${ }^{1}$ Developed as a means of internal communication, their popularity and persistence has been a feature of British companies and organizations. At their peak, their readership surpassed that of the national press, and despite the onslaught of electronic and digital media, their numbers, though diminished, remain impressive. Most major British organizations still possess a printed house magazine, whilst in some such as the British Broadcasting Corporation (BBC), they have evolved into an online version. ${ }^{2}$ It is the aim of this paper to trace the post-war history of the British house magazine to 2015 , asking what have been its key developments, what roles has it played within corporations, and does it have a future?

It should be emphasised at the outset that the term 'House Magazine' is used in this paper in a generic sense. Internal publications for staff within organisations in Britain have borne several names in their history of over a hundred years that includes house organs, company magazines, company newspapers, house journals and house magazines. ${ }^{3}$ These different terms testify to the different forms that this medium of internal organisational journalism has adopted, as will be discussed later in this paper. To maintain consistency in the paper, however, the term house magazine will be used. This was felt to be appropriate as this article covers organisations such as the BBC, Royal Mail and the National Coal Board, which while having commercial functions were nationalised and public institutions and not companies in the strictest sense of the word.

This article is based on a wide range of sources. Magazines consulted include those from the postal provider Royal Mail, the media organization the BBC, the confectioner Cadbury and the global bank the Hongkong and Shanghai Banking Corporation (HSBC). In addition, the archives of the Royal Mail, the BBC, the John Lewis Partnership (JLP), the consumer goods giant Unilever, and the Institute of Internal Communications (IOIC) have been consulted. The magazine of the Industrial Welfare Society (IWS) from 1945 to 1992 has also been examined. Finally, eight interviews were held in 2015 with editors and journalists from major British corporations. This includes the insurer the Prudential Plc, the luxury car manufacturer Jaguar Land Rover (JLR), the retailer the John Lewis Partnership (JLP), the 
postal distributor Royal Mail, the BBC, the Royal Bank of Scotland Group plc (RBS) and the media agency AB Publishing.

In relation to the four companies whose magazines have been studied in detail, some attempt has been made to provide a representative sample. Two of these were in the public sector (Royal Mail and the $\mathrm{BBC}$ ) and two were in the private sector (HSBC and Cadbury). In addition, these reflect organisations in media, distribution, manufacturing and banking. However, they are clearly not representative of all organisations in Britain and at best provide a balanced, purposive sample. It is important to note that these organisations established an internal model of labour relations based industrial welfare and internal labour markets at the end of the nineteenth century (with the BBC doing so in the 1920s) and that this model began to unravel in the 1960 s and $1970 \mathrm{~s} .{ }^{4}$ The drive to manage internal communications in the 1960s, 1970s and 1980s is indicative of this collapse and of a more managerialist approach to labour relations, where managers and workers were seen as having distinct needs and agendas. ${ }^{5}$ This was particularly pronounced at the Post Office which experienced its first national strike in 1971 and at Cadbury which underwent a major four-week strike in 1979 against the imposition of a new shift system. ${ }^{6}$ In relation to the latter, Cadbury restructured its Work Council in 1980, with less frequent meetings and the removal of health and safety, employee services and education from its remit. ${ }^{7}$ Alongside this restructuring, management briefing groups were introduced to help manage labour relations. ${ }^{8}$ As will be discussed latter, all of these organisations were under pressure to be more commercial and market focused, particularly from the 1980s onwards. Internal communication was seen as a key part of this, both in re-engineering organisational cultures and in connecting internal drives and programmes with customers and the market. This was certainly the case at the Midland Bank where deregulation and the emergence of a mass consumer market for financial services in the 1970s and 1980s placed a heavy emphasis on sales and marketing. This trend was also encouraged by technological changes in retail banking in Britain. The rise of ATM machines and centralised computer and database systems transformed bank branches into sales units, whose role was now to sell high-margin financial products such as loans and credit cards to customers. ${ }^{9}$ At the $\mathrm{BBC}$ the drive to a more commercial focus was political. Margaret Thatcher's emphasis on deregulation and consumer choice, supported by media barons such as Rupert Murdoch, threatened the public service ethos of the Corporation. With its very existence as a public broadcaster under threat, the BBC was forced to re-engineer itself as a customer focused and competitive organisation. Poll ratings and not the public good increasingly became its main prerogative. ${ }^{10}$

In relation to structure, this article will first provide a historiography of the literature on the British house magazine. Reference will also be made to historical research from North America. It will next discuss its historical development, examining areas such as the number published and readership, media format, audience responses, and the rise of agencies. Following this, the changing role of the house magazine will be examined. This is divided into three phases, 1945-1960, 1960 to 1980 and 1980 to the present. In the first period the house magazine aligned itself with a paternalistic and industrial welfare culture where the organisation was portrayed as family. In the second period one notes a shift in emphasis in house magazines from employees to the organisation, and in the third period from the organisation to customers. Within this discussion, the effect of the rise of internal communications in the 1960 s on house magazines will be examined. Finally, it will discuss the impact of digitalization on internal communication since the 1990s, and will argue that despite radical changes that this has instigated, the house magazine still has an ongoing role in a digital age. 


\section{Literature Review}

Historical discussion of British house magazines has been sparse. John Griffiths has illustrated the role of house magazines at Unilever between 1900 and 1990 in constructing and repositioning corporate culture. ${ }^{11}$ Between 1900 and 1970 the culture was based on values of family, welfare and loyalty. In the 1970s and 1980s it was transformed into one of consultative management and team work. Griffiths' work was influenced by Michael Rowlinson and John Hassard's observation that corporate cultures were essentially historical constructs that were invented by management to provide meaning for organisational life and work. ${ }^{12}$ Griffiths' contribution was to show that such cultures were subject to change - they could be re-invented - and that managed internal communication via house magazines played an important role in their manufacture.

In August 2008, a special edition on house magazines appeared in the journal Management and Organizational History. The co-editor of the journal, Michael Heller, argued that house magazines emerged in two phases in Britain. In the first period, 1880-1914, they were limited to the clerical and professional members of organizations and were often written and initiated by staff rather than managers. In the period 1914-1939, the magazine began to target all employees, spread to the largest of British companies and became more professional and managerial. ${ }^{13}$ Two papers in the special edition developed Griffiths' work on the nexus between corporate cultures and house magazines. Howard Cox focused on how the journal of the British American Tobacco Company Ltd created a corporate identity in the company in the interwar period. ${ }^{14}$ What was unique was that this identity was bottom up rather than top down. Via contributions from its staff, many of whom were based abroad, the magazine constructed a corporate ethos that was employee-centred rather than imposed by senior management. Simon Phillips' similarly examined the role of the house magazine at the British pharmacist Boots in building a corporate culture in the interwar period. ${ }^{15}$ Phillips' noted that the role of this culture was not simply to integrate workers into the company, but also acted as a means of internal propaganda by promoting the benefits that Boots offered to the nation and local communities. Magazines attempted to engineer internal consent amongst employees and counter outside criticisms concerning the size and monopolistic aspects of Boots' national chain of pharmacies. A further article by Michael Esbester examined the use of the company magazine at the Great Western Railway to implement the 'Safety First' campaign at the company between 1913 and $1939 .{ }^{16}$ Whilst on the one hand this was an account of an organizational public health campaign, on the other the paper argued that the campaign was concerned with managerial authority in its attempt to control worker's behaviour, attitudes and bodily movements. A further article by Heller between 1880 and 1939 linked the rise of the house magazine to the broader emergence of print journalism in Britain. ${ }^{17}$ Magazines were a response to the strains placed on labour relations by growth in some organizations at the end of the nineteenth century. They attempted to integrate workers into these new corporations and provide meaning and identity. In the interwar period magazines became part of the broader industrial welfare movement in Britain. In addition, they became an important supplier of information, education and diversion. ${ }^{18}$

In relation to the United States, JoAnne Yates' pioneering study showed how the rise of systematic management between 1850 and 1920, based on impersonal rules, processes and regulations, led to the development of internal communications in American corporations. Letters and word of mouth communication, based on older personal methods of management, were replaced by circular letters, notices, rule books, reports and memorandums in a bid to increase managerial control and authority. ${ }^{19}$ 
For Yates the rise of impersonal management and internal communication systems were indelibly linked. House magazines were a part of internal communication, though were closely associated with the rise of industrial welfare at the end of the nineteenth century, providing a vehicle to inform employees about what programmes were available and enhance relations between management and workers. They assisted in recreating a 'family feeling' in large organizations, and acted as a counterweight to the development of increasingly impersonal management systems. ${ }^{20}$ Magazines were aimed at defusing hostility to systematic management by workers and thus acted as a form of industrial relations. The public relations (PR) historian Roland Marchand located the house magazine in the first half of the twentieth century in efforts by American corporations to establish 'Corporate Soul' or identity, in response to widespread criticism from groups such as trade unions, liberals, journalists, local businessmen and politicians. ${ }^{21}$ Magazines endeavoured to reconnect employees with their workplace. Marchand focused on the role of the magazines in providing organizational culture and identity, often as a means of staving off the growing influence of trade unionism. Yet for Marchand, their key role was internal and external propaganda. The creation of 'corporate soul' was a powerful rebuttal to the 'mud slingers' who attacked America's young corporations. These themes were developed in the special edition of Management and Organizational History referred to above. The business and labour historians Greg Patmore and Jonathan Rees focused on how the Colorado Fuel and Iron Company used their company magazines to exert managerial control and act as antiunion devices. ${ }^{22}$ Similarly Bart Dredge showed how company magazines in southern textile towns in South Carolina between 1880 and 1940 were used as part of a strategy of corporate welfare and propaganda to impede the rise of collective organization by African-American workers. ${ }^{23}$

\section{Historical Development of the House Magazine 1945 to 2015}

During the Second World War most house magazines ceased production due to the rationing of paper by the state. This persisted in its immediate aftermath. Following this, growth in numbers was rapid. From an estimated 350 magazines in Britain in 1938, publications expanded to 1,000 by $1950 .{ }^{24}$ By 1961 it was estimated that there were 1,500 house magazines in Britain. A survey from the British Association of Industrial Editors (BAIE) in 1965, the professional association of house magazine editors and journalists formed in 1949, estimated that their readership was 17 million, one and a half million more than the national daily press. ${ }^{25}$ In the 1970s numbers continued to grow, with an estimate of 2,000 being given in $1975 .{ }^{26} \mathrm{~A}$ study by the European Industrial Editors' Association of 10 European countries in 1979 showed that Britain with 2,000 house magazines, out of a European total of 6,150, had by far the largest number of house magazines and newspapers. The second highest was France with 950, with West Germany only possessing 480. ${ }^{27}$ A survey in 1985 showed that this number had increased to 3,000 with an average readership of 9,000 and an annual expenditure by British business of $£ 33$ million. ${ }^{28}$ This was the last estimate found on the actual number of house magazines in Britain. Recent research by $A B$ Publishing, an agency that writes, designs and produces online and offline publications for business, estimated that over half of Britain's largest 250 companies still produced employee magazines and its managing director, Katie Macaulay surmised that their numbers had fallen by around a quarter over the last ten to fifteen years. ${ }^{29}$ The above figures suggest a rapid expansion in the number of house magazines from 1945 until 1990, with a sharp decline from 2000, but by no means a complete collapse. It should also be added that the many of those printed journals that ceased physical publication, such as the BBC's Ariel in 2012, continued as online staff magazines and newspapers. 
The next question regards readership. The figures that exist suggest that papers were read by around 35 to 50 per cent of staff. Sales of the Post Office Magazine are recorded as 149,120 out of a staff of 348,700 in 1949, 132,023 out of a staff of 348,060 in 1958 and 118,604 out of a staff of 383,000 in $1963 .{ }^{30}$ Sales of the Post Office's Courier staff newspaper were 135,000 out of a staff of 437,345 in $1971 .{ }^{31}$ Coal News, the staff newspaper for the miners of the National Coal Board, sold 227,000 copies in 1966, when it employed 425,500 people. ${ }^{32}$ A study of the eight magazines, the Chronicles, of the John Lewis Partnership (JLP) in 1948 found that out of 5,600 partners, 4,369 bought and read the magazine. Readership of course is not sales. Many of these papers would have been shared amongst colleagues and thus sales figures attenuated the actual readership. A further survey by JLP in 1958, for example, found that from a sample of 538 readers, 71 obtained their copies by either borrowing them or being given them. ${ }^{33}$ In addition, there is strong evidence that papers were read by family members. A survey of 820 readers of the Post Office's Courier in 1969, for example, found that 74 per cent stated that their family read the paper. The interviews confirmed that readership levels have been maintained into the present. RBS currently publishes 31,000 magazines that come out five times a year for a staff of 94,000 . The magazine is also available online in pdf format. ${ }^{34} \mathrm{JLR}$ prints 18,000 copies of their monthly magazine for a combined British workforce of 36,000. Many of their office staff read the paper online. ${ }^{35} \mathrm{JLP}$ publishes 30,000 copies of their weekly magazine, the Gazette, for 90,000 partners. In addition, they have a staff magazine for Waitrose, the supermarket branch of the group, and individual magazines for all major department stores. ${ }^{36}$

What did employees read in the magazines and what did they want from them? Audience research surveys conducted over the period suggest that British workers wanted a mixture of news about the company, information that related to their own jobs and material about their colleagues. A survey commissioned by the oil firm Shell-Mex in 1960 found that information about company activities was the most requested item. ${ }^{37}$ An article in 1965 in Industrial Welfare, the journal of the IWS, summarising the findings of readership surveys commented,

...the results of questionnaires and surveys consistently reveal that readers of house journals put three main requirements in roughly equal order of importance. They want to know something of - and to feel pride in - the achievements and policies of the organisations for which they work; they want to be kept fully informed of every company development that may affect them personally; and since there is 'no news like people', they read with the most avid interest anything about people they know and work with - so that, however trivial this may seem to the outsider, a proportion of social and personal news is essential to a successful house journal. ${ }^{38}$

The latter point is important and should avert us from assuming that workers simply wanted to hear about business news and strategy. Workers wanted content about other workers, including themselves. The popularity of the letter section, which was found in some British house magazines, is a case in point. A survey from JLP in 1958 concerning their publication, the Gazette, found that the letter section was the most read section of the magazine. ${ }^{39} \mathrm{~A}$ survey of 820 readers of the Post Office's Courier staff newspaper in 1969 similarly showed that the letter page was its most popular feature. ${ }^{40}$ When asked what items employees of the BBC read in the staff newspaper, Ariel, Cathy Loughran and Sally Hillier, both reporters and sub-editors for the newspaper from the early 1980s to 2012, commented, 
Sally Hillier: Well they read the letters page.

Cathy Loughran: Everybody read the letters page because that was ... if a letter was sent it was published. ${ }^{41}$

The fact that at the BBC and JLP management was obliged to answer letters from employees made them even more endearing to their readers.

Another area that was examined in the research was how the content of magazines changed over the period. To do this cross-sectional analysis was carried out in four house magazines, those of the Post Office, the Midland Bank, which was later acquired by and rebranded HSBC, Cadbury and the BBC. Three points were chosen, 1955, 1985 and 2005. For each a magazine was selected and content analysis was performed. The amount of content in the selected magazines devoted to social clubs and sport, the company and employees, the three core areas of house magazines was measured. The results can be seen below:

Table 1: A Content Analysis of Material on Social Clubs, Hobbies and Sports in the House Magazines of The Post Office/Royal Mail, Midland Bank/HSBC, Cadbury and the BBC for 1955, 1985 and 2004/5

\begin{tabular}{|l|l|l|l|l|l|l|}
\hline & 1955 & 1955 & 1985 & 1985 & $2004 / 5$ & $2004 / 5$ \\
\hline & $\begin{array}{l}\text { Total (\%) } \\
\text { of Articles }\end{array}$ & $\begin{array}{l}\text { Total (\%) } \\
\text { of Lines }\end{array}$ & $\begin{array}{l}\text { Total (\%) } \\
\text { of Articles }\end{array}$ & $\begin{array}{l}\text { Total (\%) } \\
\text { of Lines }\end{array}$ & $\begin{array}{l}\text { Total (\%) } \\
\text { of Articles }\end{array}$ & $\begin{array}{l}\text { Total (\%) } \\
\text { of Lines }\end{array}$ \\
\hline $\begin{array}{l}\text { Royal } \\
\text { Mail }\end{array}$ & 48.4 & 65 & 18.2 & 14.4 & 10.5 & 12 \\
\hline $\begin{array}{l}\text { Midland } \\
\text { Bank/HSBC }\end{array}$ & 46.7 & 46.5 & 43.8 & 47.9 & 4.2 & 5.7 \\
\hline Cadbury & 39.2 & 37.4 & 27.9 & 21.3 & 6.6 & 5 \\
\hline BBC & 52 & 47.4 & 5.5 & 3 & 3.5 & 3.6 \\
\hline
\end{tabular}

Sources: The Post Office Magazine, April 1955, The Courier July 1985, The Courier May 2005, The Midland Chronicle, April 1955, Midland Bank Group Newspaper, July 1985, Team Talk, May 2004, The Bourneville Works Magazine, April 1955, Cadbury News, August 1985, CTB Bites, December 2005, Ariel, Spring 1955, Ariel, July 1985, Ariel, May 2005

Table 2: A Content Analysis of Material on Company Focused Content in the House Magazines of The Post Office/Royal Mail, Midland Bank/HSBC, Cadbury and the BBC for 1955, 1985 and 2004/5

\begin{tabular}{|l|l|l|l|l|l|l|}
\hline & 1955 & 1955 & 1985 & 1985 & $2004 / 5$ & $2004 / 5$ \\
\hline & $\begin{array}{l}\text { Total (\%) } \\
\text { of Articles }\end{array}$ & $\begin{array}{l}\text { Total (\%) } \\
\text { of Lines }\end{array}$ & $\begin{array}{l}\text { Total (\%) } \\
\text { of Articles }\end{array}$ & $\begin{array}{l}\text { Total (\%) } \\
\text { of Lines }\end{array}$ & $\begin{array}{l}\text { Total (\%) } \\
\text { of Articles }\end{array}$ & $\begin{array}{l}\text { Total (\%) } \\
\text { of Lines }\end{array}$ \\
\hline $\begin{array}{l}\text { Royal } \\
\text { Mail }\end{array}$ & 25.7 & 15.1 & 29.5 & 33.7 & 34.7 & 39.9 \\
\hline $\begin{array}{l}\text { Midland } \\
\text { Bank/HSBC }\end{array}$ & 31.7 & 32.4 & 31.2 & 33 & 57.4 & 62.3 \\
\hline Cadbury & 23.9 & 18.2 & 25.6 & 32.1 & 52.6 & 62.8 \\
\hline BBC & 23.3 & 44.1 & 41.8 & 47.4 & 51.4 & 60.9 \\
\hline
\end{tabular}


Sources: The Post Office Magazine, April 1955, The Courier July 1985, The Courier May 2005, The Midland Chronicle, April 1955, Midland Bank Group Newspaper, July 1985, Team Talk, May 2004, The Bourneville Works Magazine, April 1955, Cadbury News, August 1985, CTB Bites, December 2005, Ariel, Spring 1955, Ariel, July 1985, Ariel, May 2005

Table 3: A Content Analysis of Material on Employee Focused Content in the House Magazines of The Post Office/Royal Mail, Midland Bank/HSBC, Cadbury and the BBC for 1955, 1985 and 2004/5

\begin{tabular}{|l|l|l|l|l|l|l|}
\hline & 1955 & 1955 & 1985 & 1985 & $2004 / 5$ & $2004 / 5$ \\
\hline & $\begin{array}{l}\text { Total (\%) } \\
\text { of Articles }\end{array}$ & $\begin{array}{l}\text { Total (\%) } \\
\text { of Lines }\end{array}$ & $\begin{array}{l}\text { Total (\%) } \\
\text { of Articles }\end{array}$ & $\begin{array}{l}\text { Total (\%) } \\
\text { of Lines }\end{array}$ & $\begin{array}{l}\text { Total (\%) } \\
\text { of Articles }\end{array}$ & $\begin{array}{l}\text { Total (\%) } \\
\text { of Lines }\end{array}$ \\
\hline $\begin{array}{l}\text { Royal } \\
\text { Mail }\end{array}$ & 22.7 & 18.5 & 25 & 28.3 & 35.8 & 31.4 \\
\hline $\begin{array}{l}\text { Midland } \\
\text { Bank/HSBC }\end{array}$ & 7.6 & 9.1 & 11.3 & 9.8 & 25.6 & 18.7 \\
\hline Cadbury & 20.2 & 30.8 & 37.3 & 30.1 & 18.4 & 13.5 \\
\hline BBC & 3.9 & 3 & 30.9 & 35.3 & 22.8 & 24.4 \\
\hline
\end{tabular}

Sources: The Post Office Magazine, April 1955, The Courier July 1985, The Courier May 2005, The Midland Chronicle, April 1955, Midland Bank Group Newspaper, July 1985, Team Talk, May 2004, The Bourneville Works Magazine, April 1955, Cadbury News, August 1985, CTB Bites, December 2005, Ariel, Spring 1955, Ariel, July 1985, Ariel, May 2005

The analysis demonstrates major structural changes in the content of house magazines in the selected organisations over the three selected years. There was a collapse in articles covering social clubs, hobbies and sports from an average of 49.1 percent of total lines in 1955 to 6.6 percent in 2004/5. Similarly there was a steep rise in the amount of space dedicated to company focused matters from an average of 27.5 percent in 1955 to 56.5 percent in 2004/5. A small rise occurred in the amount of space given to employee focused content from 15.4 percent in 1955 to 22 percent in 2004/5, though this declined from 25.9 percent in 1985. What is of interest is that these trends are more or less constant across all organisations. Whilst there was some variation, for example social clubs, hobbies and sports were still an important feature of content at the Midland Bank in 1985, company focused content is more pronounced at the BBC and Midland Bank in 1955 and employee focused content became less important at Cadbury and more central in the other three organisations, the overall similarity in the trends across all four is clearly noticeable. Effectively house magazines became far less concerned between 1955 and 2005 in the social side of organisations and far more pre-occupied with work. Between 1945 and 2015 house magazines became increasingly detached from a discourse of social welfare and far more focused on narratives of industrial relations and later marketing.

A further important area of change was in terms of format. As a result of the house magazine becoming more popular following 1945 and available not just to management and white-collar staff but to all workers, many changed from magazines to newspapers, with some, particularly in sectors employing large numbers of manual workers, adopting tabloid forms. A survey by the BAIE in 1973, for example, showed that newspapers and newsletters accounted for half of the internal journals covered by the survey. This was compared to $83 \%$ of these journals being magazines in 1958 and $63 \%$ 
in $1969 .{ }^{42}$ By the 1970 s the house journal had adopted a wide number of formats that included magazines, tabloids, broadsheets (predominantly for management) and smaller bulletins and newsheets, whose role was to rapidly disseminate news. As the house magazine expanded it segmented itself, adopting different forms and content for different groups of employees.

Another area of change was the physical production of house magazines. Until the 1990s the vast majority were published in-house. Whilst external printers sometimes produced the final product, the BBC's Ariel, for example, was published by Broadwater Press Ltd of Welwyn Garden City in 1955, Buck Free Press Group of High Wycombe in 1985 and by the Garnett Dickinson Group of Rotherham in 2005, the journalism, editing, layout and design was done by teams of employees within the organization. Indeed, in the 1960s and 1970s one can note an increase in the number of people working on magazines and newspapers within companies and a rise in professionalism. ${ }^{43}$ Companies began to employ journalists, usually with experience in local newspapers. The larger corporations such as the National Coal Board, British Rail, and JLP had teams of editors, sub-editors, reporters and regional reporters that began to resemble newspaper offices. ${ }^{44}$ Of the four house magazines examined in detail in this paper the Post Office (1970s) and the BBC (1990s) heavily invested in such teams of journalists with the result that these journals began to adopt semi-independent editorials. This partially accounts for the switch from house magazines to company newspapers, as in the change at the Post Office from The Post Office Magazine to The Courier in 1966. ${ }^{45}$ In the 1990s, however, external publishing houses, themselves employing teams of journalists, began to produce house magazines for companies who outsourced them to these agencies. While the four house magazines examined in the article kept publication in-house until 2005, the publication of Royal Mail's Courier was outsourced to Redwood Publishing in 2007 and to $A B$ publishing in 2011. ${ }^{46}$ It is interesting to note that Redwood had been purchased by the BBC in 1989 as part of BBC Enterprises but was never used it to publish Ariel. ${ }^{47}$

An indication of this shift is a membership survey of the British Association of Communicators in Business (former BAIE) in October 1995. Only half the Association's membership worked in-house, down from three quarters ten years earlier, while a quarter worked for agencies and another quarter worked freelance. ${ }^{48}$ In the 1990s and 2000s these agencies began to merge and expand. Some merged with American companies, and others became part of larger media, advertising, marketing and PR agencies. ${ }^{49}$ By 2005 the trend towards outsourcing house magazines had become so great that a debate around in-house versus out-house publications had developed. Arguments for out-house revolved around lower costs, agencies having experience of other organizations and their ability to furnish neutral, third party perspectives. Arguments for in-house publications rested on the need to be close to employees, to understand organizational culture and brands, and the creation of continuity, depth and knowledge. ${ }^{50}$

Some organisations produced simultaneously several house magazines aimed at different segments of organisational members and customers. As early as the 1920s, for the example, the Prudential Assurance Company, Britain's largest provider of life insurance had two house journals. For its clerical staff at its headquarters Holborn Bars in London, it produced The Ibis Magazine. For its sales team who visited the homes of its customers and were rarely at the company it published The Prudential Bulletin..$^{51}$ The latter was far more focused on work and provided articles on education, sales and marketing techniques, developments in the life insurance market in Britain and company news. Similarly, in the 1960s the National Coal Board, one of the largest employers in Britain, produced four magazines. These were Coal News, a tabloid company paper aimed at coal miners, their families and 
communities, Management News, a twelve-page broadsheet for the management of the organisation, which contained articles on policy, operations and new developments, Coal Quarterly, a thirty-page prestige magazine targeted at industrial users of coal, MP's, editors and other influential stakeholders and Partnership, an eight-page journal published as a supplement in the trade magazine, Coal Merchant. ${ }^{52}$ Perhaps the most extensive example of this was the consumer goods global giant Unilever. An examination of its magazines for the year 1964 at its archive revealed twelve house magazines being simultaneously produced by the company. This included corporate Unilever publications such as Progress, Unilever Information Bulletin, Port Sunlight News and Unilever International. House magazines for individual companies within the group such as Wall's Magazine, Oxo Extracts and Birds Eye Views and international publications such as Inspan, for Unilever in South Africa, The Palm Bulletin, the newsletter of the Palm lines Limited Shipping Company and Link, the magazine of the United African Company, Unilever's principal subsidiary in Africa, for Nigeria.

\section{Roles of House Magazines}

\section{5-60: The Organisation as Family}

Following the Second World War British house magazines continued to follow an older discourse that had been established in the fifty years before 1939. From 1945 until the early 1960s one sees continuity rather than change. While they grew in number, their purpose and role remained the same; to re-establish bonds that had been broken by the growth in organizations, to create a feeling amongst staff of belonging, commonly referred to as esprit de corps, and to provide information. ${ }^{53}$ In addition, house magazines continued to be viewed as part of a broader system of industrial welfare. ${ }^{54}$ This argued that employers had a fundamental responsibility to look after the well-being of their employees in areas such as health, safety, work environment, education, and benefits. It differed from older forms of paternalism in that such welfare was argued to be a responsibility of companies rather than a result of the idiosyncratic benevolence of individual employers. ${ }^{55}$ Within this, communication between management and employees was an essential feature. In an article in Industrial Welfare and Personnel Management in 1950, for example, G.A. Whipple, chairman and managing director of the scientific tools manufacturer Hilger and Watts, Ltd., commented, 'In my view the main function of the works magazine is to recapture for the large unit the spirit, keenness, enthusiasm and interest which is the happy possession of the small firm with the right "Guvnor". ${ }^{56}$ Its function was to foster pride and maintain interest within the larger organization and to provide information for employees in matters concerning their job, the factory and the broader industry. In his article, Watts emphasised information on new products and the performance of the company.

Such continuity can also be detected in the GPO. A PR report in 1944 commented in relation to the recommencement of the Post Office Magazine,

We record our opinion...that a substantial financial contribution is well justified in view of the great value of the Magazine as a means of contact between the Department and its staff and between sections of the staff themselves. The benefits in this respect cannot be measured in terms of money but we feel strongly that reasonable financial assistance attaching to the production of a well-run staff magazine should not be looked upon as a subsidy but rather as a valuable investment in internal public relations. ${ }^{57}$ 
Similarly, a report in 1950 commented that, 'The purpose of the Magazine is to stimulate esprit de corps among the staff as a whole; to encourage the sense that we are all 'one big family' engaged on 'united operations.' ${ }^{58}$ During this period the Post Office Magazine remained firmly in the purview of the PR department of the GPO.

This emphasis on belonging and welfare in house magazines in Britain was highlighted in 1950 in a speech in London by Miss Helen Baker, Associate Director of the Industrial Relations Section, Princeton University. ${ }^{59}$ She contrasted American internal communications with those in Britain. The focus in American was on efficiency and greater productivity. Baker listed these as informing workers of company plans, policies and objectives so as to obtain a favourable attitude, to strengthen managerial responsibility and encourage independence of action, and to give information on operating plans to secure greater productivity. Unions supported the upward flow of information to inform management of workers' opinions. In Britain, in contrast, the emphasis was on a desire for unity. Baker stated, 'Her impression was that "making everyone happy" and "all of us getting on with the job" were often the limits to which the object of communications had been defined. ${ }^{60}$ Whilst in the U.S.A communication was used as a tool by management to facilitate its decisions, in Britain its aim was integrate different points of view. Her impression was that, "British industry's desire for unity was frequently greater than its knowledge of the purpose of that unity." 61 Whilst Miss Baker's opinions were clearly her own, they furnish a poignant outsider's view on British house magazines and internal communication.

\section{0s to 1970s: A Shift in the Focus of Magazines from Employees to the Organisation}

In the 1960s and 1970s many house magazines in Britain underwent a transition. From being PR channels, attempting to engineer organizational 'imagined communities', they increasingly were used as a tool of industrial relations. ${ }^{62}$ This was in response to a rise in trade union militancy in Britain and an increase in strike action, especially in the 1970s. In the period 1960-64 117 hours were lost per 1,000 workers due to industrial action, for 1965-69 this was 145, for 1970-74 this had rocketed to 441 and for 1975-79 had increased to $477 .{ }^{63}$ Much of this was due to inflation and growing demands for a higher standard of living. Under such conditions, local union leaders, or shop stewards, increasingly took control from central union bosses. Unions became more difficult to control, more volatile and much more disruptive. ${ }^{64}$ Low points in Britain included the three-day week, from January to March 1974, when shops, factories and other businesses were limited to three day's supply of electricity, and the Winter of Discontent, during the autumn and winter of 1978 to 1979, when national strikes led to power black outs, rubbish uncollected in the streets, and at its most extreme, the dead remaining unburied. ${ }^{65}$

A perceived cause of this industrial action was British management's inability to communicate with workers. Better communication was increasingly voiced as the panacea to Britain's industrial relations. For example, an article in Industrial Welfare in 1963 commented,

Communication is industry's current catchword. A touch of this talisman is the cure, it seems, for almost all the problems that hamper good industrial relations. Heads wag approvingly every time someone says "What we need is better communications," or "If only we had had better communications this trouble would never have arisen." Somewhere, somebody is saying it often. And, moreover, often saying it with truth. ${ }^{66}$ 
As a result, the role of house magazines became more strategic. They began to switch from PR to industrial relations departments, with input from personnel managers. Their function now was to communicate managerial policy to workers and foster better industrial relations. Older notions of welfare and esprit de corps were abandoned. ${ }^{67}$ This was assisted by a growing emphasis on management's need and responsibility to communicate with workers. ${ }^{68} \mathrm{~A}$ key figure in this development was John Garnet, the director of the Industrial Society from 1962 to 1986, an organisation, including its predecessor, the Industrial Welfare Society, which played an important role in the propagation and development of the House Magazine and Internal Communication. For Garnet making work worthwhile, and creating a sense of employee involvement and commitment was the key industrial challenge of the age. ${ }^{69}$ Absenteeism, turnover and strikes were all consequences of a failure to do this. ${ }^{70}$ Much of the responsibility of creating a sense of worker engagement fell on management. They had a duty to make goals, processes and achievements clear and involve employees in this, down to the smallest work groups. ${ }^{71}$ At the heart of this lay the need for managers to communicate, and not in the old-fashioned top down, authoritarian manner, but in a much more symmetrical two-way mode, in which information flowed upwards and downwards and was transparent and clear. ${ }^{72}$

Such a shift in communication can be exemplified by Coal News at the National Coal Board (NCB). Coal News was a company newspaper written in tabloid form. It was staffed by professional journalists who were given editorial freedom to report on the coal industry. ${ }^{73}$ It was launched in July, 1961 and replaced the former house magazine of the NCB. The paper's sales grew from 40,000 for the first issue to over 200,000 by the eighteenth issue. Coal News reported on controversial topics such as pit closures and wages. It criticised management and portrayed itself as the newspaper of coal miners. ${ }^{74}$ For Lord Robens, the Chairman of the NCB and a proponent of Coal News, such independence was indispensable. As he stated,

The editor must have the freedom which is given to other newspaper editors - the freedom to decide the newspaper's policy, to express opinions, and he should be free to open his pages, if he so decided, to criticism of managerial policy. This certainly seemed sensible and essential to me for producing a real newspaper and not a propaganda sheet which couldn't do an effective communication job, wouldn't sell anyway, and would end up where it belonged - in the waste paper basket. ${ }^{75}$

It was argued that due to this independence, industrial relations were enhanced between management and workers. Restructuring and change were able to take place without industrial action. As evidence, Robens pointed to rising productivity in pits and the successful restructuring of the British coal industry, with miners being transferred to expanding mines in central England. ${ }^{76}$ This had taken place with fewer industrial disputes than earlier, in an overall economic context where they were increasing. For an industry that saw employment fall from around 607,000 in 1960 to 290,000 in 1970, and the closure of 400 pits, this was impressive. ${ }^{77}$

Coal News' model of independent journalism was copied in other major industries in Britain in the $1960 \mathrm{~s}$ in a bid to improve management-worker communication and industrial relations. ${ }^{78}$ As a report by the GPO noted in 1966, in relation to the launch of the new staff newspaper Courier, 'The newspaper will play an extremely important part in providing the staff rapidly and at all levels with information they need to know and which management wants them to know, in improving morale 
and so increasing efficiency and improving management-staff relationships. ${ }^{79}$ House magazines increasingly were divided into two categories by commentators, those that provided workers with useful information and aimed at improving labour and industrial relations, and those that were simply prestige journals, filled with stories about social clubs, the boss, and births, deaths and marriages. ${ }^{80}$ An article in Industrial Society in 1969 made the distinction between those house magazines that were still wedded to the 'stigmas' of welfare and paternalism and wrote in the communication style of the early 50s, and those that had slimmed down and modernised and were ready for the 1970s. These were written by specialists, explained company strategy, focused on two-way communication, and provided information that employees needed to do their work satisfactorily. ${ }^{81}$

\section{The Integration of House Magazines into a Wider Internal Communication Strategy in Organisations}

In the 1960s and 1970s a new managerial discourse and practice of internal communications (IC) developed in Britain. It can be detected in the literature of the Industrial Society, in the British Institute of Management, in companies such as Ford, the NCB and the Post Office, and amongst certain management academics and theorists..$^{82}$ IC took a more rigorous approach to internal organizational communication. It began from the premise that much of the problems of Britain's industrial relations was based on management's failure to communicate. This had a profound impact on house magazines.

IC was based on several principles. The first was that it was a tool of management. The Industrial Society booklet on the subject noted, 'It ... deals with the problems managers in factories and offices and public services face in getting their decisions and policies understood by those who have to carry them out, and with ways of keeping in touch with the views of those for whom the manager is ultimately responsible. ${ }^{\prime 83}$ At the Post Office, its purpose was to produce higher productivity by helping workers understand what their roles and aims were, appreciate and accept these aims and understand how they fitted into the greater organization. IC was posited as a means to enhance managerial authority, particularly vis-à-vis trade unions. As a report on the subject noted,

We believe that after the war the Post Office deliberately under-played its direct communicating role and left the field open for the unions. As a natural consequence, the unions took on more and more of the substance of communication between management and staff. ${ }^{84}$

IC was consequently positioned as a muscular form of management communication that was able to deliver strategic benefits for companies. This included a reduction in work stoppages, successful change management and greater productivity. ${ }^{85}$

The second feature of IC was its utilisation of different forms and channels of communication. The Industrial Society specified three tools; direct communication by managers and supervisors to those groups of employees they had responsibility for, often referred to as briefing groups, discussion through representational committees made up of members of management and employees, and mass methods of communication such as house magazines and notice boards. These had distinct functions. The first was to communicate and explain instructions, information and policy, the second was to discuss organizational change, and the third was to provide mass means of communicating the firm's activities and policies and creating a sense of worker involvement in the company. ${ }^{86}$ In relation to channels, beyond the traditional ones of noticeboards, memos, house magazines, mass-meetings, and 
newsletters, one can point to an array of electronic devices that began to proliferate in the $1960 \mathrm{~s}$ and 1970s such as closed circuit television (CCTV), videos, telephone call-in centres and computers.

A third feature of IC was that it was integrated and targeted. Mass systems of communication were intended, for example, to reinforce communication from briefing groups. The Post Office's Internal Communication Study Group made a distinction between 'background information', that is communication that provided history, context and rationale, and 'specific information' that was aimed at committing employees to particular activities or change. ${ }^{87}$ The former supported the latter. In addition, channels were meant to be integrated. Internal communication audits were to be routinely carried out to ensure that all channels of communication were operating inside organizations, articulating consistent messages to targeted groups. As an article in Industrial Relations noted,

Internal communications management today is characterised by a lack of consistent direction in communication policy - using the company publication in one direction, the supervisory network in another, management circulars and bulletins in another, booklets, group meetings, films, whatever, in others. Too often there is no central management and communications policy on how to focus on the priorities determined by management. ${ }^{88}$

In contrast, IC was based on an integration of these channels. In relation to targeted groups, IC often followed the marketing practice, developed in the 1960s and 1970s, of segmentation, targeting and positioning. Different groups in the company such as workers, supervisors and technical staff were targeted with different messages and systems of communication. ${ }^{89}$

While IC did not necessarily discard house magazines, it delimited their role, seeing them as part of a larger system of communication. As a result, the house magazine was demoted. It was no longer the primary means of communication within large-scale organizations, but simply one of an array of tools and channels. The role of information provision was essentially stripped from it, given now to briefing groups, the new 'golden boy' of internal communications in the 1960s and 1970s. The role of the house magazine was reduced to one of providing background information, of reinforcing and supporting other tools and channels of IC. ${ }^{90}$ This can be detected in the rise of a debate in the BAIE in the 1970s concerning the changing role of the association, due to changes in its wider environment and the need to focus on IC. As its chairman, John Makin, noted at its Annual General Meeting, on May $21^{\text {st }}, 1973$, 'What I would suggest is that technology will mean that we will have to consider whether or not this Association should be concerned simply with house journals as we know them or should be broadening its base to embrace a much wider range of communication techniques and activities. ${ }^{\prime 1}$ It was to be a debate that would last until May, 1995, when the members of the BAIE after several failed votes, finally agreed to change their name to the equally cumbersome, British Association of Communicators in Business. ${ }^{92}$

The tables below show other channels of IC that were used at the BBC, Midland Bank/HSBC, Cadbury and Royal Mail beyond that of the house magazine. Mirroring the content analysis tables, the three cross sectional years of 1955, 1985 and 2005 were chosen. In addition to showing what channels were being used it briefly outlines the function of each channel.

Table 4: Internal Communication Channels at The British Broadcasting Corporation in 1955, 1985 and 2005 


\begin{tabular}{|c|c|c|c|c|}
\hline Channel & $\begin{array}{l}\text { Function } \\
\end{array}$ & 1955 & 1985 & 2005 \\
\hline Circulars & $\begin{array}{l}\text { One-way information. Appointments, } \\
\text { instructions and new regulations. }\end{array}$ & Yes & Yes & No \\
\hline Notice Boards & Announcements and events & Yes & Yes & Yes \\
\hline Films & $\begin{array}{l}\text { Educational. In } 2005 \text { they were used } \\
\text { to broadcast new initiatives and } \\
\text { strategy }\end{array}$ & Yes & Yes & Yes \\
\hline Liaison Meetings & $\begin{array}{l}\text { Two-way discussion meetings to } \\
\text { discuss new initiatives. Mainly at } \\
\text { senior level }\end{array}$ & Yes & Yes & Yes \\
\hline Posters & $\begin{array}{l}\text { Informational, propaganda and } \\
\text { educational }\end{array}$ & Yes & Yes & Yes \\
\hline $\begin{array}{l}\text { Staff } \\
\text { Association/Union- } \\
\text { Management } \\
\text { Committee }\end{array}$ & $\begin{array}{l}\text { Discussion and liaison between } \\
\text { management and staff to discuss } \\
\text { work, wages, employment and labour } \\
\text { relations }\end{array}$ & Yes & Yes & Yes \\
\hline Briefing Groups & $\begin{array}{l}\text { Two-way meetings to discuss and } \\
\text { disseminate policy and strategy. } \\
\text { Cascaded down the organisation }\end{array}$ & No & Yes & Yes \\
\hline Visual Display Units & $\begin{array}{l}\text { Used to provide news, bulletins and } \\
\text { broadcast Director General Liaison } \\
\text { Meetings }\end{array}$ & No & Yes & Yes \\
\hline Local Newsletters & $\begin{array}{l}\text { Provide news and updates at the local } \\
\text { level }\end{array}$ & Yes & Yes & No \\
\hline Mass Meetings & $\begin{array}{l}\text { Dissemination of new initiatives and } \\
\text { policy }\end{array}$ & No & Yes & Yes \\
\hline CCTV & $\begin{array}{l}\text { Broadcasting of news and new media } \\
\text { content }\end{array}$ & No & Yes & Yes \\
\hline Audio/Loud Speakers & $\begin{array}{l}\text { Used to broadcast Director General } \\
\text { Liaison and Mass Meetings }\end{array}$ & No & Yes & No \\
\hline $\begin{array}{l}\text { Telephone } \\
\text { Conferences }\end{array}$ & Used for Meetings & No & Yes & Yes \\
\hline Internal Phone Ins & $\begin{array}{l}\text { Bottom-up communication that } \\
\text { enabled staff to question senior } \\
\text { management on policy and strategy } \\
\text { initiatives }\end{array}$ & No & Yes & No \\
\hline Intranet & $\begin{array}{l}\text { Highlighting of new BBC media } \\
\text { content. Provision of corporate } \\
\text { information such as changes in policy } \\
\text { and organisational change. Enables } \\
\text { staff to manage their own matters } \\
\text { such as annual leave, salary and } \\
\text { administrative areas. }\end{array}$ & No & No & Yes \\
\hline Email & $\begin{array}{l}\text { One-way communication to } \\
\text { announce news, regulations and new } \\
\text { initiatives. Two-way communication } \\
\text { between staff }\end{array}$ & No & No & Yes \\
\hline
\end{tabular}


Sources: BBC Written Archives Centre (WAC) R49/295/1, 'Staff Policy Instructions Nos. 379-452, 1945-1946'; BBC WAC R49/1070 Communications Internal, 'Memo from Director of Technical Services to C.S.A. through D.A. November 3, 1955'; R78/1, 900/1 'Internal Communication Policy 1953-1978'; BBC WAC R78/4, 172/1, 'DMD TELS Working Party on Internal Communication, 1979'; BBC WAC R78/4, 173/1, 'Circulars and Directives August 71969 to April 3 1989'; Interview with Yogesh Chauhan, Deputy Head of Corporate Social Responsibility at the BBC in 2005, November 23, 2017.

Table 5: Internal Communication Channels at The Midland/Hong Kong Shanghai (UK) Bank, 1955, 1985 and 2004

\begin{tabular}{|c|c|c|c|c|}
\hline Channel & Function & 1955 & 1985 & 2004 \\
\hline Circulars & $\begin{array}{l}\text { One-way information. } \\
\text { Appointments, instructions, policy } \\
\text { and new regulations. }\end{array}$ & Yes & Yes & Yes \\
\hline Management Meetings & $\begin{array}{l}\text { Discussion of introduction of new } \\
\text { schemes and major changes in } \\
\text { policy }\end{array}$ & Yes & Yes & Yes \\
\hline $\begin{array}{l}\text { Management Visits to } \\
\text { Branches }\end{array}$ & $\begin{array}{l}\text { Supervision and communication to } \\
\text { staff of new schemes and changes in } \\
\text { policy }\end{array}$ & Yes & Yes & Yes \\
\hline Management Clubs & Social meetings of managers & Yes & No & No \\
\hline Staff Handbook & $\begin{array}{l}\text { Explanation and information on } \\
\text { conditions of service }\end{array}$ & Yes & Yes & Yes \\
\hline Films & Education and training & No & Yes & Yes \\
\hline Pamphlets & $\begin{array}{l}\text { One-way information. New policy } \\
\text { developments, instructions and new } \\
\text { regulations. }\end{array}$ & No & Yes & Yes \\
\hline Audio-Visual & Broadcasting of news & No & Yes & Yes \\
\hline $\begin{array}{l}\text { Staff Information } \\
\text { Bulletins }\end{array}$ & Provision of information & No & Yes & Yes \\
\hline Annual Reports & Annual performance of the bank & No & Yes & Yes \\
\hline $\begin{array}{l}\text { BBM-System } \\
\text { Instructions }\end{array}$ & $\begin{array}{l}\text { Communication of rules and } \\
\text { instructions }\end{array}$ & No & Yes & Yes \\
\hline $\begin{array}{l}\text { Staff Suggestion } \\
\text { Schemes }\end{array}$ & $\begin{array}{l}\text { Discussion, explanation and } \\
\text { engagement between bank and staff }\end{array}$ & No & Yes & No \\
\hline Briefing Groups & $\begin{array}{l}\text { Two-way meetings to discuss and } \\
\text { disseminate policy and strategy. } \\
\text { Cascaded down the organisation }\end{array}$ & No & Yes & Yes \\
\hline $\begin{array}{l}\text { Marketing/Product } \\
\text { Knowledge Meetings }\end{array}$ & $\begin{array}{l}\text { Dissemination of information on } \\
\text { new marketing initiatives and new } \\
\text { products. Training and instruction }\end{array}$ & No & Yes & Yes \\
\hline Intranet & $\begin{array}{l}\text { Provision of electronic documents. } \\
\text { Change management. Bank } \\
\text { procedure manuals. Furnishing of } \\
\text { real time information. Staff-user } \\
\text { generation and management of new }\end{array}$ & No & No & Yes \\
\hline
\end{tabular}




\begin{tabular}{|l|l|l|l|l|}
\hline & $\begin{array}{l}\text { documents and content. } \\
\text { Information on customers. Enables } \\
\text { staff to manage their own matters } \\
\text { such as annual leave, salary and } \\
\text { administrative areas. }\end{array}$ & & & \\
\hline Emails & $\begin{array}{l}\text { One-way communication to } \\
\text { announce news, regulations and } \\
\text { new initiatives. Two-way } \\
\text { communication between staff }\end{array}$ & No & No & Yes \\
\hline CDs & Training and education & No & No & Yes \\
\hline Counselling Services & $\begin{array}{l}\text { Counselling, advice and information } \\
\text { to staff and their families }\end{array}$ & No & No & Yes \\
\hline
\end{tabular}

Sources: HSBC Archives UK 0200-0235b, Internal Comms Group, 'Report on Internal

Communications, April 1961'; HSBC Archives UK 1617-044, Management/Staff Communications

Review by Charles Baker Lyons, 'Minutes of Meeting to Discuss Terms of Reference for a

Communications Audit/Study, on Wednesday 12 January 1983'; HSBC Archives UK 1493, 'Group

Circulars, 1955'; Team Talk, 'Top billing for bank videos', June, 2003, p. 10; Team Talk, 'Open Line offers more help to all employees', June, 2003, p. 14; Team Talk, 'Intranet comes of age with world of knowledge', August, 2003, pp. 12-13; Team Talk, 'Risky business', March, 2004, p. 8; Team Talk, 'The screen age is here', March, 2004, p. 7.

Table 6: Internal Communication Channels at Cadbury, 1955, 1985 and 2005

\begin{tabular}{|c|c|c|c|c|}
\hline Channel & Function & 1955 & 1985 & 2005 \\
\hline Circulars & $\begin{array}{l}\text { One-way information. Appointments, } \\
\text { instructions, policy and new } \\
\text { regulations }\end{array}$ & Yes & Yes & Yes \\
\hline Read-Out Statements & $\begin{array}{l}\text { Statements read to groups of staff } \\
\text { from management. Dealt with } \\
\text { changes and policy }\end{array}$ & Yes & No & No \\
\hline Noticeboards & Announcements and Events & Yes & Yes & Yes \\
\hline Works Council/Union & $\begin{array}{l}\text { Discussion and liaison between } \\
\text { management and staff to discuss } \\
\text { work, wages, employment and labour } \\
\text { relations }\end{array}$ & Yes & Yes & Yes \\
\hline Videos & $\begin{array}{l}\text { Shown to groups of workers. } \\
\text { Broadcasted speeches by managing } \\
\text { directors giving their views on the } \\
\text { confectionary business and provision } \\
\text { of new policy initiatives }\end{array}$ & No & Yes & Yes \\
\hline Conference & $\begin{array}{l}\text { Discussion of policy, strategy and } \\
\text { drives between management and staff } \\
\text { representatives. Broadcast to staff } \\
\text { through the house journal }\end{array}$ & No & Yes & Yes \\
\hline Briefing Groups & $\begin{array}{l}\text { Two-way meetings to discuss and } \\
\text { disseminate policy and strategy. } \\
\text { Cascaded down the organisation }\end{array}$ & No & Yes & Yes \\
\hline
\end{tabular}




\begin{tabular}{|l|l|l|l|l|}
\hline Pamphlets/Leaflets & $\begin{array}{l}\text { Outlines new policies, initiatives and } \\
\text { internal events }\end{array}$ & No & Yes & Yes \\
\hline Staff Handbook & $\begin{array}{l}\text { Explanation and information on } \\
\text { conditions of service }\end{array}$ & No & Yes & Yes \\
\hline
\end{tabular}

Sources: Cadbury Archives, Mondelez International 913.12-001163, '1948 Statement Read to Staff'; Cadbury Archives 913.12-001163, 'Management Staff Circular Somerdale, 1949'; Cadbury Archives 913-001167, 'Management Staff Circulars, 1924-1976'; Cadbury News, 'The Company Character', Oct-Nov, 1984, p. 9, Cadbury News, 'A Positive Response to Communications Survey', December, p. 3; Cadbury News, 'Video Message gas a Woolworth Backcloth', April, 1985, p. 9; Cadbury Archives 330-010929, 'Your Guide to Working at Cadbury, [Handbook]c. 2005'; Cadbury Archives 349-012098, '100 Years CDM, 2005'.; Interview with Sarah Foden, Archives and Information, Resources Manager, Mondelez International, November 23, 2017.

Table 7: Internal Communication Channels at The Post Office/Royal Mail, 1955, 1985 and 2005

\begin{tabular}{|c|c|c|c|c|}
\hline Channel & Function & 1955 & 1985 & 2005 \\
\hline Memos & $\begin{array}{l}\text { Two-way communication to send } \\
\text { messages, information, instructions } \\
\text { between members of staff. Can also } \\
\text { be used one-way as circulars }\end{array}$ & Yes & Yes & No \\
\hline Posters & $\begin{array}{l}\text { Informational, propaganda and } \\
\text { educational }\end{array}$ & Yes & Yes & Yes \\
\hline Films/Videos/DVDs & $\begin{array}{l}\text { Educational, training, propaganda and } \\
\text { internal marketing (by 1985) }\end{array}$ & Yes & Yes & Yes \\
\hline Noticeboards & $\begin{array}{l}\text { Announcements and events. Later } \\
\text { used to support face to face } \\
\text { discussion in shift huddles and } \\
\text { listening and learning groups }\end{array}$ & Yes & Yes & Yes \\
\hline Reports & $\begin{array}{l}\text { Communication of policy and strategy } \\
\text { based on detailed research. } \\
\text { Educational, instructional and used as } \\
\text { basis for discussions in meetings }\end{array}$ & Yes & Yes & Yes \\
\hline $\begin{array}{l}\text { Staff } \\
\text { Association/Union- } \\
\text { Management } \\
\text { Committee }\end{array}$ & $\begin{array}{l}\text { Discussion and liaison between } \\
\text { management and staff to discuss } \\
\text { work, wages, employment and labour } \\
\text { relations }\end{array}$ & Yes & Yes & Yes \\
\hline $\begin{array}{l}\text { Briefing } \\
\text { Groups/Listening and } \\
\text { Learning Groups } \\
(2005)\end{array}$ & $\begin{array}{l}\text { Two-way meetings to discuss and } \\
\text { disseminate policy and strategy. } \\
\text { Cascaded down the organisation. } \\
\text { Later (2005) used for staff } \\
\text { involvement, engagement and team } \\
\text { management }\end{array}$ & No & Yes & Yes \\
\hline Seminars & $\begin{array}{l}\text { Dissemination of information and } \\
\text { training }\end{array}$ & No & Yes & Yes \\
\hline Leaflets/booklets & $\begin{array}{l}\text { Educational and informational. Also } \\
\text { used in packs with films for internal } \\
\text { marketing. }\end{array}$ & Yes & Yes & Yes \\
\hline
\end{tabular}




\begin{tabular}{|c|c|c|c|c|}
\hline Newsbriefs & $\begin{array}{l}\text { Single sheet news briefs - } \\
\text { informational, news and instructions. } \\
\text { They resemble memos }\end{array}$ & No & Yes & No \\
\hline Insight & $\begin{array}{l}\text { Management magazine. Contains } \\
\text { information, news and policy } \\
\text { developments }\end{array}$ & No & Yes & No \\
\hline Shift huddles & $\begin{array}{l}\text { Small face to face team meetings. } \\
\text { Health checks to ensure people know } \\
\text { and understand their goals for the day } \\
\text { and how they will be achieved }\end{array}$ & No & No & Yes \\
\hline Ops Daily & $\begin{array}{l}\text { Operations sheets for managers that } \\
\text { contain daily instructions and goals } \\
\text { that are to be actioned. }\end{array}$ & No & No & Yes \\
\hline Intranet & $\begin{array}{l}\text { Used for HR purposes, operations, } \\
\text { training, guidelines for staff and } \\
\text { management, documents, advice, } \\
\text { staff development }\end{array}$ & No & No & Yes \\
\hline Emails & $\begin{array}{l}\text { One-way communication to announce } \\
\text { news, regulations and new initiatives. } \\
\text { Two-way communication between } \\
\text { staff }\end{array}$ & No & No & Yes \\
\hline
\end{tabular}

Sources: RMA POST 110, 'Internal Relations Panel [Poster], 1950-1968'; POST 122/1193, 'Joint Production Panel: Internal Relations Panel: films on communication, 1950-1959'; POST 73/343, 'Internal Communication Briefing Groups, February 1972'; POST 154/121, 'Video Production: Internal Communication Marketing 1984, 1984-85': POST 72/1103, 'Newsbrief Internal Briefing Service, 11 March - 24 August 1987'; POST 65, 'The Post Office Gazette, 1985'; POST 92/1542, 'Insight, 1983'; POST 63/220, 'Involving and Engaging Our People: A Manager's Guide, 2004'; POST 108/441, 'The Ant Campaign: A video that's about our brilliant campaign, 2003'; POST 68/1301.

In many respects the companies show similar trajectories. In addition to house magazines, the main forms of IC that were used in 1955 were circulars/memos, notice boards and posters. By 1985 the rise of a far more robust form of internal communications can be noted. Briefing groups can be seen in all four companies accompanied by more use of meetings and conferences audio/visual channels such as film and CCTV. Two-way communication channels began to supplement the former one-way channels. In 2005 digital forms of communication were added to the suite of internal communications in the form of intranets and emails, which allowed IC to be tailored more to the needs of individual employees. However, it should be noted that changes were far more pronounced in some organisations than others. Briefing groups, for example, were far more vigorous and used more intensely at the Post Office/Royal Mail and at HSBC than they were at Cadbury and the BBC. ${ }^{93}$ Electronic forms of communications were more developed in 1985 and 2005 at the BBC than they were in other organisations, particularly Cadbury, which had failed to adopt digital communication in 2005. While IC was similar in these companies its use and rate of adoption varied.

1980s to the Present: An Increasing Emphasis in House Magazines on Customers Rather than Employees 
In the early 1980s, the house magazine's role in industrial relations was resumed as a result of mass industrial action caused by the British Prime Minister Margaret Thatcher's economic reforms and closure of a major segment of Britain's mining and manufacturing industry. Following this, house magazines, buffeted by developments in their business and managerial environment, began another stage of evolution. This was precipitated by new managerial concepts and practices, such as organizational culture, corporate identity, corporate branding, internal marketing, and change management. ${ }^{94}$ As a result of Thatcher's emphasis on free markets, deregulation and consumer choice, the PR and marketing industries boomed in Britain in the 1980s and have continued to do so over the last thirty years. ${ }^{95}$ These broader changes impacted on the house magazine. From tools of industrial and employee relations, they increasingly began to adopt a commercial role. Their function was now to internally market the products and services that companies sold in order to generate employee buy-in, communicate marketing campaigns and create 'brand ambassadors' amongst the workforce. It was also to generate attitudinal changes amongst employees. Organizations were now to be customer-centric in the new quest for markets and profits. Understanding and satisfying consumer needs increasingly became the modus operandi of British industry. Such refocusing demanded changes in employee's behaviour and outlook, and the house magazine was enlisted to help engineer this cultural change. Under such conditions it was given a new lease of life. As the BAIE noted in 1989,

The growing preoccupation of the business world with profits and results has also had an effect on BAIE and its members. On the one hand, many of us have benefitted as individuals, because good communications are at last acknowledged to be an essential element for commercial success; we are no longer preaching in the wilderness, but have found a ready audience. ${ }^{96}$

The changes that the 1980s had engendered were demonstrated in a seminar organised by the Industrial Society in 1991 entitled, 'Corporate Identity and its impact on internal communications'. ${ }^{97}$ At the seminar the communication consultant, Colette Dorward noted that,

Many organisations are reshaping their strategies to provide customers with what they want, rather than the former practice of what they considered their customers ought to have ... This commitment to the customer was often expressed forcibly in advertising and sales promotion. However, it was essential that management should complete the equation by harnessing the support of their employees and making it clear what the company was trying to achieve. ${ }^{98}$

An example of this was given at the seminar by British Telecom's (BT) corporate affairs team. They gave a presentation on the recent repositioning of the newly privatised telecoms company's corporate identity. This was based on focusing on customers and an eschewal of its old public sector image. Organizational symbols, logos, values, behaviour and communication were all changed. BT's extensive internal publications were part of this upheaval. As one of the presenters noted, 'Employee communications need to adapt and truly reflect the aspirations of the company's change of direction. ${ }^{\prime 99}$

The role of the house magazine in creating new organizational cultures that were more customercentric was a prominent theme in the interviews with editors. At RBS, the principal focus of its current magazine, 'Outside In' has been to facilitate a change in the culture of the bank to make it more customer focused. This is based on four values; working together, doing the right thing, serving 
customers and thinking long-term. The content of the magazine is structured on these four principles. Stories, often told through accounts of actual employees at the bank, are designed to exemplify these mores and reinforce the aspired values and culture of the organization. ${ }^{100}$ For the luxury car manufacturer JLR, the chief role of the house magazine has been to create a corporate culture and identity for a newly merged company, owned now by the Tata Group. As its editor noted,

When we were brought together as Jaguar and Land Rover we had to go through a big culture change to mesh the two companies with two very different ways of working. So for the first few years it was about let's get the two brands integrated, let's get them working, let's just concentrate on that. We then moved into almost stage two which was let's try and build a culture now because we're all working together, we're all ticking along, now let's try and build some common messages or some affinity between the two, what we both stand for and why do we both come into work. ${ }^{101}$

The new culture is customer focused, based on delivering, 'experiences customers love for life'. It has been embedded into its entire suite of internal communications, including its house magazine. As its editor noted, 'it was woven into all of our stories, all of our messaging'. ${ }^{102}$ Such a culture was said to be fundamental in clarifying to employees what it meant to work for JLR. The importance of aligning employees with organizational culture was mentioned several times by the interviewees and was often referred to as engagement. ${ }^{103}$ Interviewees commented that house magazines were not simply concerned with delivering information, but with embedding individuals within the company's system of values, and its corporate strategies and policies.

Encapsulated in this tilt towards the market was a renewed focus on customer magazines, the external equivalent of the house magazine that was used to promote the company and its products to targeted customers and stakeholders. Customer magazines have been a key aspect of many company's marketing strategies in Britain for over a hundred years and in the first half of the twentieth century appear to have been larger in number than internal house magazines. In 1939, Francis R. Groves of the Institute of House Organ Editors, the first association for house magazines in Britain, estimated that there were 360 House Organs in Britain. ${ }^{104}$ He divided these between staff magazines, sales organs, distributors' house organs, consumer house organs and association journals. Of these only fifty-seven were staff magazines. ${ }^{105}$ By far the largest single grouping was house organs to consumers and the public,that numbered one hundred and eighty-five. ${ }^{106}$ Peter Scott in his recent book on the mass marketing of consumer goods in Britain in the interwar period has highlighted the importance of customer magazines in the engineering of mass consumption in areas such as home and car ownership. ${ }^{107}$ In the 1980s customer magazines underwent an expansion in Britain and became far more customer and market focused. ${ }^{108}$ An excellent example of this is Highlife, the customer inflight magazine of British Airways which began in 1973 and continues today. The magazine portrayed and emphasised a luxurious, hedonic and international jet setting lifestyle. ${ }^{109}$ Many of the articles on regions and travel were essentially destination marketing pieces, which highlighted the attractions of certain places, whether these were cultural, recreational, culinary or sporting. ${ }^{110}$ The aim of Highlife was to promote a certain way of life that involved international travel and consumption, provide information on British Airways products that involved not just flights but also hotels, holidays and associated services such as car hire, and promote specific destinations. By the 1980s it was also publishing articles on topics such as holiday fashion, skin protection from the sun and children's holidays that were effectively public relations pieces that exercised product placement and 
branding. ${ }^{111}$ The magazine informed, educated, entertained and subtly sold a very broad array of products to passengers.

It should be noted, however, that this tilt towards the commercial was not passively accepted by all house magazines. Some, particularly those with more independent editorial boards, were highly critical at the rise of marketing and customer focused logics within their organisations and industries. A case in point was Ariel at the BBC. On the announcement of the cessation of the printing of Ariel in 2011, the Guardian newspaper wrote, 'Ariel has been a persistent thorn in the side for BBC bosses since its launch 75 years ago, providing an outlet for staff to air their grievances ... and an invaluable source of stories about the corporation for media correspondents. ${ }^{\prime 12}$ Much of this was due to the arrival of Andrew Harvey as editor of the magazine from 2001 to 2009. Harvey had been a professional Fleet Street journalist and had previously edited the Saturday Review of The Times. With the backing of Director Generals Greg Dyke (who had brought him into the BBC) and then Mark Thompson, Harvey created an Ariel that had a semi-independent editorial and was at times critical of the BBC and of management. ${ }^{113}$ Former Ariel journalists and assistant editors Cathy Loughran and Sally Hillier recalled that before Harvey's arrival Ariel had a times been a mouthpiece of management and was controlled by the Corporation, after his arrival the newspaper became semi-independent and had much more leeway. Once installed as editor Harvey launched a number of campaigns including cutting bureaucracy and waste within the BBC. During the interview Sally Hillier commented,

And he [Harvey] absolutely infuriated managers at board level, like the finance director, for example, who had to be scraped off the ceiling. Because of the campaigns, you know, he said these are ten things the BBC had to do to cut red tape. This is Andrew Harvey, bang, bang, bang, bang. Bullet points on the front page. ${ }^{114}$

During both the crisis that shook the BBC in January/February 2004 with the forced removal of the popular Director General Greg Dyke following the Hutton Report and strikes by members of the National Union of Journalist at the BBC in November, 2010 as a result of pension reforms at the Corporation, Ariel maintained an independent stance and published articles and letters from staff that were highly critical of management. ${ }^{115}$ Yet despite this, Harvey and an independent Ariel was supported by senior management at the BBC including the Director General. ${ }^{116}$ Similar to Lord Robens approach at the NCB in the 1960s, discussed above, it was felt that a critical and semi-independent Ariel created trust, engagement and transparency at the BBC. ${ }^{117}$ The newspaper put across management's point of view as well as other stakeholders such as unions and journalists. ${ }^{118}$ All stories contained both sides of any given argument or controversy and perhaps most importantly Ariel provided facts and information during times of crisis at the BBC and so precluded rumour, the grapevine and misinformation. ${ }^{119}$ Under such conditions it is no wonder that the paper, despite being a thorn in its side, was supported by management.

\section{The Ongoing Role of House Magazines in the Digital Age}

One other change since the 1980s that has impacted on the house magazine has been its role within the communication mix of IC. Much of this has been due to the impact of the internet and the rise of internal digital communications. On the one hand, the period has seen continuities in the communication roles of house magazines. Their function is still to provide background information, and to amplify and reinforce communication by briefing groups. The editor of JLR's house magazine clearly outlined this process of IC at the luxury car manufacturer. This typically goes through three 
stages. The first is board engagement where the CEO communicates messages to his senior managers. This is then communicated by the latter to the top 250 managers beneath them who then go on to brief their teams. Using the briefing group method, messages are thus 'cascaded' down the various levels of the company. Stage three is amplification. This is when the same messages are broadcasted by the magazine and other mass methods of communication back up the organization in order to reinforce messages that are coming down. This can be done by repetition, explanation and exemplification, often by writing articles on what is happening amongst colleagues that are linked to specific messages. ${ }^{120}$

Yet at the same time, the rise of digital media has revolutionized IC and has impacted on house magazines. The last twenty years has seen the rise of ezines, internets, intranets, chat forums, emails, and social media sites such as Yammer that have facilitated internal communications between organizations, management and employees. Digital media has several distinct advantages over print media and other forms of off-line communication. It is direct, immediate, two-way, interactive, usergenerated, and has access to multiple forms of media such as videos, electronic office documents and web-sites. ${ }^{121}$ Digital media in most organizations is now the preferred choice for news and information delivery, which has further eroded the role and usefulness of the house magazine. In many organisations, such as at Aviva and the Prudential, the two largest insurance companies in Britain, Cadbury and at the BBC, digital media has replaced house magazines. ${ }^{122}$ The rise of digital media thus poses a more serious existential threat to the house magazine than the rise of the briefing group and other forms of electronic media in the 1960s and 1970s.

Yet research has demonstrated that while in some cases digital media has replaced print media, in others the two support each other. Many of the interviews with house magazine editors attested to this. In many cases, for example, news stories will appear on intranets as teasers, creating publicity for the content, before they appear in full version in the magazine. Extended versions of printed stories often appear online, with the opportunity for employees to post comments and often get involved in discussion on online chat forums. ${ }^{123}$ In addition, house magazines were said to have several distinct advantages over digital media. In sectors such as retail and distribution, and in factories and even call centres, employees do not have access to digital media. ${ }^{124}$ Print is still necessary. In addition, many employees still prefer to read magazines. As several interviewees pointed out, people who work behind computers all day do not want to digitally read the company newssheet. They often prefer to read it in their free time when on a coffee break, on the bus or train to and from work, or at home. ${ }^{125}$ Related to this, the portability and tangibility of the house magazine gives it distinct advantages. It can be stored, commemorated or simply carried around for a further read. ${ }^{126}$ Finally, the ability to develop long explanatory or contextual articles that deal with company issues or news stories was given as a distinct advantage. ${ }^{127}$ Two interviewees made the distinction between fast and slow journalism. ${ }^{128}$ The former, related to digital media, is involved with the rapid delivery of important information. The latter, linked to house magazines, focuses on explaining and discussing in detail this communication. The two complemented each other. At RBS, for example, its editor explained this through the example of a recent change that had been made in relation to the training of staff around mortgages the bank sold. Whilst fast journalism could announce the change, slow journalism, through a magazine article, could discuss what was different about the bank's approach to mortgages, what that meant for staff and how it was benefitting customers. ${ }^{129}$ It is interesting to note in relation to RBS, that in a recent survey the printed version of the bank's magazine received higher ratings for trust, and made people feel more proud to work for the bank than the same stories found on the website. ${ }^{130}$ 


\section{Conclusion}

Since the Second World War the house magazine has experienced a turbulent history. Its function has changed from one of creating a sense of organizational belonging, to managing industrial relations to the present goal of engineering market and customer focused cultures. Within this, much of its earlier role of providing news and information, and reporting on and contributing to the social life of the organization has disappeared. It has also changed physically. At the beginning of the period most were magazines. By the 1970s roughly half were newspapers, but by the 2010's most had switched back to magazine format and some have become purely electronic. ${ }^{131}$ Production has also changed. Whilst the house magazine was previously created in-house, they are increasingly written and edited by external agencies. Finally, the rise of IC and digitalization has radically recalibrated the house magazine. From being the sole form of mass organizational communication, they have emerged since the 1970s as one medium in a suite of channels of internal communication. Their role now is to amplify and provide context and background, rather than to break news and inform employees. Digitalization has catalysed this process. Whilst for some companies, the former has brought about the end of the house magazine, in others it has learnt to adapt to $24 / 7$ digital communication, just as it had earlier learnt to adjust itself to briefing groups, IC, television and other electronic forms of communication. The house magazine since 1945 has experienced growth, decline but ultimately survival. It has helped facilitate the rise of IC and has taught management the importance of communicating to its employees. It has adapted to historical changes both within organizations and in its external environment. In many respects, the historical study of the house magazine in the United Kingdom has acted as a barometer for its broader organizational, business and management history.

This article has taken the unorthodox path for a historical paper of examining something from the past and extending its analysis to the present. It will make one final transgression by trying to look into the future. Based on what has been discussed, the question of whether the British house magazine has a future can be asked. Whilst most internal communication is now electronic, printed journalism has survived, despite many predictions to the contrary. New house magazines continue to appear, such as The Lot, a tabloid launched for the British timber and building materials supplier Jewson in 2012. ${ }^{132}$ Awards such as for best Newspaper, Feature-Led Magazine and New Publication from the Institute of Internal Communications, the present-day successor to the BAIE, continue to attract a large number of entries from British business. ${ }^{133}$ In addition, rather than constituting a threat, it would appear that digital communications offer new opportunities. A report commissioned by AB Publishing in 2012, entitled, 'Is the employee publication dead?' concluded that 'technology is enabling paper and screen to unite in new ways. Rather than killing print, it seems that multimedia content could be its saviour.' ${ }^{134}$ These conclusions are supported by the interviews. The editor of 'Courier', at Royal Mail, noted that some organizations that had removed their printed house magazines had been forced to reintroduce alternative forms of internal print media. ${ }^{135}$ The archivist at John Lewis observed that it would be very difficult for the retail partnership to operate without its house magazine, The Gazette. The role it provides in supplying not just news, but also a corporate ethos and culture has made it indispensable. ${ }^{136}$ It would appear safe to argue that so long as British companies are in need of the former, and so long as print media continues to complement digital media, the British house magazine should survive into the foreseeable future. 
${ }^{1}$ Heller, "British Company Magazines 1878-1939." House magazines are also referred to in the article as company magazines or newspapers.

2 InsideOut, 'Axe for Ariel', November, 2011, 4.

3 Heller, "British Company Magazines".

${ }^{4}$ Gospel, Markets, Firms, and the Management of Labour, chapter 4.

5 Ibid., chapter 7.

${ }^{6}$ Campbell-Smith, Masters of the Post, 497-504; Smith, Child and Rowlinson, Reshaping Work, 213.

7 Ibid., 211.

8 Ibid., 212.

${ }^{9}$ Batiz-Lazo, Cash and Dash, chapter 9.

${ }^{10}$ Curran and Seaton, Power without Responsibility, chapter 15.

11 Griffiths, "'Give My Regards to Uncle Billy..."

12 Rowlinson and Hassard, "The Invention of Corporate Culture."

13 Heller, "Company Magazines 1880-1940: An Overview."

${ }^{14}$ Cox, "Shaping a Corporate Identity from Below."

15 Phillips, "'Chemists to the Nation'."

${ }^{16}$ Esbester, "Organising Work."

17 Heller, "British Company Magazines".

18 Ibid.

19 Yates, Control through communication.

20 Ibid., 74-77, 192-199.

21 Marchand, Creating the Corporate Soul.

22 Patmore and Rees, "Employee Publications."

${ }^{23}$ Dredge, "Company Magazines and the Creation of Industrial Cooperation."

${ }^{24}$ Industrial Welfare and Personnel Development, "Employee Magazines," May-June, 1946, 98; The Industrial

Editor, "The Modern Solution to a Modern Problem," Autumn, 1950, 7.

25 Industrial Welfare, "The Industrial Scene," April, 1965, 58.

${ }^{26}$ Ibid., "Controversy or complacency," January/February, 1975, 17.

27 BAIE News, "No Controversy Please - We're British," October, 1979, 1.

28 Ibid., "Roy Watts announces survey results," October, 1985, 3.

${ }^{29}$ Interview with Katie Macaulay.

${ }^{30}$ RMA 122/8935, Post Office Newspaper and Management News, 'Proposal for a Post Office Newspaper', December, 1963.

31 RMA 151/55, ICSG First Report, 'Post Office Management Board Internal Communications Paper by DPR', July, 1971.

32 Industrial Society, "Coal News is not a boss's paper," August 1966, 193-194.

33 John Lewis Archives, 386/M, 'What Partners Think about the Gazette,' July, 1958.

${ }^{34}$ Interview with Leanne Cornelius, 16 June, 2015.

35 Interview with Richard Streeton, 14 December, 2015.

${ }^{36}$ Interview with Steven Forfar, 6 October, 2015.

37 Industrial Welfare, "Why many house magazines fail in their purpose," July/August, 1961, 238.

38 Industrial Welfare, "Readership surveys make the job of communicating a two-way business," October, 1964, 242.

39 John Lewis Archives, 386/M, 'What Partners Think about the Gazette,' July, 1958.

${ }^{40}$ RMA POST 72/584, 'A Report on the Survey of Staff Opinion on Courier Carried Out in July 1969'.

41 Interview with Cathy Loughran and Sally Hillier, 12 June, 2015.

42 BAIE News, "More papers, more money," April 1973, 1.

43 RMA POST 151/85, 'Courier Formation and Staffing 1964-68'.

${ }^{44}$ RMA POST 122/8935, 'Post Office Newspaper and Management News'.

${ }^{45}$ Ibid.; Industrial Welfare, "Why does the shape of a house journal determine its effectiveness as a medium of communications," June 1965, 146-150.

46 Interview with Keira Hammond, 9 October, 2015.

${ }^{47}$ Cox and Mowatt, Revolutions from Grub Street, 132.

${ }^{48}$ Crucible, "Survey show one in four members now freelances," December, 1995, 3.

49 BAIE News, "Merger Mania grips agencies," May, 1995, 1; CiB News, "Merger shake-up brings old pals together," November, 2001, 4. 
50 Communicators, 'The word about writers', July, 2005, 4-5.

51 Heller, "British Company Magazines."

52 RMA, POST 122/8935, Post Office Newspaper and Management News, 'Tell the Workers Your Aims', 21 January, 1963.

${ }^{53}$ The Industrial Editor, "The Role of the House Journal in Industry," Autumn, 1953, 61-63.

54 Heller, "British Company Magazines," 153-156; Mayo, The Human Problems of an Industrial Civilization.

55 Fitzgerald, British Labour Management.

56 Industrial and Personnel Management, 'The Function of the Works Magazine', May-June, 1950, 82-85.

${ }^{57}$ RMA, POST 33/5963, Post Office Magazine: Republication After World War Two. 1944-1950, 'Post Office

Public Relations Study Group Interim Report', 29 ${ }^{\text {th }}$ August, 1944.

58 Ibid., 'Post Office Magazine. Notes for Regional Directors Conference, July, 1950', 4th July, 1950.

59 Industrial Welfare and Personnel Management, "Company Communications: Comparison between Britain and the U.S.A.," November-December, 1950, 180.

60 lbid.

61 Ibid.

62 Gospel, Markets, Firms, and the Management of Labour, chapter 7.

63 Brown, "Industrial Relations and the Economy 1939-1999."

${ }^{64}$ Addison, No Turning Back.

65 Ibid., 273-275.

66 Industrial Welfare, 'Keeping people informed is a specialist's job', October, 1963, 268.

67 Ibid., 'Spelling it out', August, 1969, 165-166.

68 Industrial Society, "Spelling it out," August, 1969, 165-166.

${ }^{69}$ Garnet, The Work Challenge.

70 lbid., 1.

71 lbid., chapter 3.

72 Ibid., chapter 8 .

73 The Times, 'Tell Workers Your Aims", 18 January, 1963, 5.

74 Industrial Welfare, 'Keeping people informed is a specialist's job', October, 1963, 270.

75 Ibid., 'Coal News is not a boss's newspaper Lord Robens', August, 1966, 193-194.

76 Ibid., 194.

77 Sanbrook, State of Emergency, 113.

78 RMA, POST 122/8935, Post Office Newspaper and Management News, 'Proposal for a Post Office

Newspaper', December, 1963.

79 Ibid., 'Post Office Newspaper', 10 August, 1966.

80 The Financial Times, 'He who pays the piper...' , 8 July, 1969, 15.

81 Industrial Society, 'Spelling it out', August, 1969, 165-166.

82 RMA POST 151/61, 'Internal Communication Study Group - Minutes, Agendas and Chairman's Briefs, 19721974 '.

83 The Industrial Society, Notes for Managers, 3.

${ }^{84}$ RMA, POST151/55, ICSG First Report With Management, File 1, 'Report of the Internal Communication Study Group', p. 3.

85 Industrial Society, Notes for Managers, 3-4.

86 Industrial Society, Notes for Managers.

87 'Report of the Internal Communication Study Group', 8-9.

${ }^{88}$ Industrial Society, 'Are you telling them what they need to know?' July, 1971, 11.

89 Ibid.

90 Industrial Society, Notes for Managers

91 BAIE News, 'Prepare for the Future', 1.

92 Ibid., 'Members vote for new name at EGM', 1.

93 RMA 73/343 Internal Communication Briefing Groups, 'North Eastern Postal Region Report, February 1972'; HSBC Archives UK 1617-0044, 'Management/staff communication review by Charles Baker Lyons, 1975'; Internal Communication Audit - Midland Bank, 1983'.

94 See Ollins, Corporate Identity.

95 Davis, Public Relations Democracy; Schwarzkopf, 'From Fordist to creative economies."

96 BAIE 1949-1989 A BAIE News Souvenir, '80s - time to look ahead not to dwell on the past'.

${ }^{97}$ BAIE News, "Internal publications must adapt to corporate ID," August, 1991, 8.

98 Ibid.

25 
99 Ibid.

100 Interview with Leanne Cornelius.

101 Interview with Richard Streeton.

102 Ibid.

103 Ibid; Interview with Leanne Cornelius; Interview with Keira Hammond.

104 Groves, The House Organ Handbook, 13.

105 Ibid., 96.

106 Ibid., 165.

107 Scott, The Market Makers, 82 \& 273.

108 Cox and Mowatt, 133-135.

109 British Airways Heritage Centre, Highlife Magazine, 'The Night We Went to Epernay by Way of Tours-surMarne Rolling British drunkard Alan Coren reports from Champagne', April/May, 1973, 14-15; Highlife Magazine, 'Continent Hopping Robert Morley on the pleasures of braking long journeys with an exotic "stopover"', July, 1983, p. 20-22.

110 Ibid., 'The Posh and Becks Guide to Madrid', October, 2003, 60-64.

111 Ibid., 'Chic Plus Comfort Ann Ryan on co-ordinating your holiday wear', July, 1983, 67-71.

112 The Guardian, 'BBC to stop printing Ariel magazine after 75 years', October 20, 2011.

113 Interview with Cathy Loughran and Sally Hillier.

114 Ibid.

${ }^{115}$ Ariel, 'Goodbye to a good guy', February 3, 2004, 6-7; Ariel, 'Too Little too Late?', 19 October, $2010,10$.

116 Interview with Cathy Loughran and Sally Hillier.

117 Ibid.

${ }^{118}$ Ariel, 'We've apologised and now we're ready to move on', February 3, 2004, 1; Ariel, 'Strikes will change nothing says BBC', 9 November, 2010, 3.

119 Ibid., Ariel Hutton Special, 29 January, 2004; Ariel, 'How big is the deficit and why do we have to wait to find out?', 16 November, 2010, 10.

120 Interview with Richard Streeton.

${ }^{121}$ Insideout, Prophet of doom! Will the 'digital mag age' bring you revolution or revulsion?' March, 2011, 6-7.

122 Communicators, 'All-electronic is a winner', October, 2004, pp. 12-13; InsideOut, 'Axe for Ariel', November, 2011, p. 4; Interview with Peter Krinks, June 2015.

${ }^{123}$ Interview with Peter Krinks; Interview with Leanne Cornelius; Interview with Steven Forfar; Interview with Keira Hammond; Interview with Richard Streeton.

${ }^{124}$ Interview with Keira Hammond; Interview with Steven Forfar.

125 Interview with Leanne Cornelius.

126 Interview with Keira Hammond; Interview with Katie Macaulay.

127 InsideOut, 'Survival of the fittest. Why company magazines must evolve or die', January, 2011, 20-21.

128 Interview with Leanne Cornelius; Interview with Katie Macaulay.

129 Interview with Leanne Cornelius.

130 Ibid.

${ }^{131}$ BAIE News, "More papers, more money," April, 1973, 1.

132 InsideOut, "New tabloid challenges digital trend," November, 2012, 9.

133 Interview with Keira Hammond.

134 InsideOut, "Is the employee publication dead?" July, 2012, 10.

135 Interview with Keira Hammond.

${ }^{136}$ Interview with Judy Faraday, 21 September, 2015.

\section{References}

Addison, A. No Turning Back The Peacetime Revolutions of Post-War Britain. Oxford: Oxford University Press, 2010.

Batiz-Lazo, B. (forthcoming) Cash and Dash: How ATM and Computers Changed Banking. Oxford: Oxford University Press.

Brown, W. "Industrial Relations and the Economy 1939-1999." in The Cambridge Economic History of Modern Britain Volume 3, eds. Roderick Floud and Paul Johnson, Cambridge: Cambridge University Press, 2004. 
Campbell-Smith, D. Masters of the Post. The Authorized History of The Royal Mail. London: Allen Lane, 2011.

Cox, H. "Shaping a Corporate Identity from Below: The Role of the BAT Bulletin." Management \&

Organizational History 4, nos. 3-4 (August/November 2008): 197-215.

Cox, H. and S. Mowatt. Revolutions from Grub Street A History of Magazine Publishing in Britain. Oxford: Oxford University Press, 2014.

Curran, J. and J. Seaton. Power without Responsibility. The Press and Broadcasting in Britain. Routeldge: London, 1997.

Davis, A. Public Relations Democracy. Manchester: Manchester University Press, 2002.

Dredge, B. "Company Magazines and the Creation of Industrial Cooperation: A Case Study from the Southern Textile Industry, 1880-1940." Management \& Organizational History 4, nos. 3-4 (August/November 2008): 273-288.

Esbester, M. "Organising Work: Company Magazines and the Discipline of Safety." Management \& Organizational History 4, nos. 3-4 (August/November 2008): 217-237.

Fitzgerald, R. British Labour Management and Industrial Welfare, 1846-1939. London: Croom Helm, 1933.

Garnet, J. The Work Challenge. London: The Industrial Society, 1973.

Gospel, H.F. Markets, Firms, and the Management of Labour in Modern Britain. Cambridge: Cambridge University Press, 1992.

Griffiths, J. "'Give My Regards to Uncle Billy...': The Rites and Rituals of Company Life at Lever Brothers, c. 1900-c.1990." Business History 37, no. 4 (1995): 25-45.

Groves, F.R. The House Organ Handbook and Review. London: Institute of House Organ Editors, 1939.

Heller, M. “Company Magazines 1880-1940: An Overview." Management \& Organizational History 4, nos. 3-4 (August/November 2008): 179-196.

Heller, M. "British Company Magazines 1878-1939: The Origins and Functions of House Journals in Large-Scale Organisations." Media History 15, no. 2 (2009): 143-166.

Marchand, R. Creating the Corporate Soul: The Rose of Public Relations in American Big Business. Berkeley, CA.: University of California Press, 1998.

Mayo, E. The Human Problems of an Industrial Civilization. New York: Macmillan, 1933.

Ollins, W. Corporate Identity. London: Thames and Hudson, 1989.

Patmore, G. and J. Rees. "Employee Publications and Employee Representations Plans: The Case of Colorado Fuels and Iron, 1915-1942." Management \& Organizational History 4, nos. 3-4 (August/November 2008): 257272.

Phillips, S. "'Chemists to the Nation': House magazines, locality and health at Boots The Chemists 1919-1939." Management \& Organizational History 4, nos. 3-4 (August/November 2008): 239-255.

Rowlinson, M. and J. Hassard. "The Invention of Corporate Culture: A History of the Histories of Cadbury." Human Relations 46, no. 3 (1993): 299-326.

Sandbrook, D. State of Emergency: The Way We Were Britain 1970-1974. London: Penguin, 2011.

27 
Schwarzkopf, S. "From Fordist to creative economies: the de-Americanisation of European advertising cultures since the 1960s." European Review of History 20, no. 5 (2013): 859-879.

Scott, P. The Market Makers: Creating Mass Markets for Consumer Durables in Inter-war Britain. Oxford: Oxford University Press, 2017.

Smith, C.J., J. Child and M. Rowlinson, Reshaping Work: The Cadbury Experience. Cambridge: Cambridge University Press, 1990.

The Industrial Society. Notes for Managers Number 2 The Manager's Responsibility for Communication. London: The Industrial Society, 1974.

Yates, J. Control through communication: the rise of system in American management. Baltimore, Md.: John Hopkins University Press, 1993.

\section{Interviews}

Interview with Leanne Cornelius, RBS, June 16, 2015.

Interview with Steven Forfar, JLP, October 6, 2015.

Interview with Judy Farraday, JLP, September 21, 2015.

Interview with Kiera Hammond, Royal Mail, October 9, 2015.

Interview with Peter Krinks, Prudential, June 5, 2015.

Interview with Cathy Loughram and Sally Hillier, BBC, June 12, 2015.

Interview with Katie Macaulay, AB Publishing, November 5, 2015.

Interview with Richard Streeton, JLR, December 14, 2015. 
